\title{
Learning under conditions of hierarchy and discipline: the case of the German Army, 1939-1940
}

\author{
Max Visser
}

Received: 1 November 2007/ Accepted: 27 May 2008/Published online: 6 June 2008

(C) The Author(s) 2008

\begin{abstract}
To survive in and adapt to dynamic, turbulent, and complex environments, organizations need to engage in learning. This truism is particularly relevant for army organizations in times of war and armed conflict. In this article a case of army operations during World War II is analyzed on the basis of Örtenblad's integrated model of the learning organization and Argyris and Schön's theory of action approach. Among others, it is found that survival of and adaptation to combat conditions is possible through singleloop learning, provided that this learning takes place in an open and productive learning climate. This and other conclusions have important implications for theory and practice of organizational learning under conditions of hierarchy and discipline.
\end{abstract}

Keywords Learning organization - Army organization · After action reports · Learning climate $\cdot$ Trust $\cdot$ Leadership

Army organizations are relatively seldom studied by organization scientists, probably due to unfamiliarity with (or even repugnance to) military affairs, the dangers in acquiring data, and a shared image of armies as simple, routine-ridden "machines" (Morgan 1997; Moskos 1984; Mutch 2006; Talbot 2003). This lack of attention, however, does not seem fully justifiable. Armies constitute the world's oldest large-scale organizations, representing centuries of experience in surviving arguably the most competitive, turbulent and dynamic situation an organization may encounter, i.e., actual war. Moreover, the image of armies as hierarchical and bureaucratic "machines" seems at odds with the degree of flexibility and adaptation current organization theory requires of organizations in such turbulent and dynamic situations (March and Weissinger-Baylon 1986; Wilson 1989). In other words, army organizations seem to pose a "learning paradox" here.

\footnotetext{
M. Visser ( $\square)$

Nijmegen School of Management, Radboud University, P.O. Box 9108, 6500 HK Nijmegen, The Netherlands

e-mail: m.visser@fm.ru.nl

URL: www.ru.nl/fm/visser
} 
Of all armies, the Prussian (and later the German) Army usually is portrayed as the most "machine-like" (Morgan 1997; Talbot 2003; Wilson 1989). This army is often associated with rigid hierarchy ("Befehl ist Befehl") and strict discipline ("Kadavergehorsam"), which characteristics do not seem conducive to a flexible adaptation to the contingencies of war. Yet, despite this association and in spite of having lost Word War II, military historians generally agree that the German Army was one of the most adaptive and flexible armies in that war (e.g., Dupuy 1984; Hart 2001; Murray 1992; Van Creveld 1983). Apparently, the German Army had found ways to resolve the "learning paradox" and to combine conditions of hierarchy and discipline with adaptability and flexibility. This was so, primarily because the German Army was organized in accordance with many aspects currently associated with the learning organization, as this paper purports to show.

In this paper I analyze a particular case of German Army operations on the basis of Örtenblad's integrated model of the learning organization and the theoretical framework of Argyris and Schön. Recognizing the ambiguity of the concept of learning organization in the work of early proponents like Senge (1990), and on the basis of an extended literature review and synthesis, Ortenblad $(2002,2004,2007)$ distinguishes four aspects, discussed in detail below, which must be present for an organization to be properly called "learning." The framework of Argyris and Schön (1974, 1978, 1996) complements this model by explicitly furthering insight into two of these aspects and implicitly supporting two others. More in general, Argyris and Schön were the first to depart from a purely descriptive, academic-oriented approach to analyzing organizational learning and to adopt a more prescriptive, practice-oriented approach to developing learning organizations (EasterbySmith and Lyles 2003; Easterby-Smith et al. 2004; Tsang 1997). The army case involved is the Polish campaign and its aftermath (1939-1940), which case more than later German operations shows the significance of learning from past events for future performance.

This paper proceeds first with a brief outline of the model of Ortenblad and the theoretical framework of Argyris and Schön. Second, this framework is applied to the German Army's Polish campaign and its aftermath, drawing on secondary military and historical sources. Finally, conclusions are drawn and implications sketched for present organizations, and a few cautionary notes are made.

\section{The learning organization: an integrated model}

On the basis of Örtenblad $(2002,2004)$ and Argyris and Schön $(1974,1978,1996)$ four aspects may be distinguished that must be present for an organization to be appropriately labeled a learning organization.

\section{Organizational learning}

The first aspect is organizational learning, in which agents learn for the organization, the results of which are stored in organizational memory. Central to such learning, according to Argyris and Schön, is the cyclical relationship between knowledge and action. Human action should lead to more effective knowledge, which in its turn should lead to more effective action. Argyris and Schön express this relationship in the cognitive concept of theory of action, which has the general form: "in situation $S$, if you want to achieve consequence $C$, under assumptions $a_{1} \ldots a_{n}$, do $A$ " (Argyris and Schön 1974, p. 6). The assumptions constitute a model of the world, in which it is likely that action strategy $A$ will 
lead to consequence $C$ in situation $S$. Besides these elements, theories of action contain governing variables, norms, and values that make consequence $C$ desirable or worthwhile to achieve.

Learning starts when actual consequences of an action strategy do not correspond with expected consequences. This discrepancy between expectation and result is considered an error and leads to a problematic situation, which calls for a period of reflection and inquiry by the acting organizational members. Learning then involves the detection and correction of error on the basis of inquiry. It may be accomplished by single-loop learning (in which members mitigate the discrepancy between expected and actual consequences by adjusting their action strategy $A$ and assumptions $a_{1} \ldots a_{n}$, but without changing their norms and values that make consequence $C$ desirable) or by double-loop learning (in which members mitigate the discrepancy between expected and actual consequences by adjusting their action strategy $A$, assumptions $a_{1} \ldots a_{n}$, and by changing their norms and values that make consequence $C$ desirable). Double-loop learning thus involves a more profound and deep way of learning than single-loop learning.

In addition, Argyris and Schön $(1978,1996)$ distinguish deutero-learning as a form of higher learning, relative to single-loop learning and double-loop learning. ${ }^{1}$ To learn to single-loop learn implies learning to improve performance at an increasing rate. To learn to double-loop learn implies learning to carry out reflection on and inquiry into the governing variables, norms, and values underlying organizational action.

Argyris and Schön link individual to organizational learning by pointing out that, by virtue of delegated responsibilities, some organizational members are empowered to speak and act on behalf of the whole organization, not only in top positions, but in every role or function dealing with external relations. Those members learn when they experience the discrepancy between consequences of an action, expected on the basis of organizational theory of action, and actual consequences. If the organization as a whole is to learn, then the corrective actions these members undertake on the basis of a reflective inquiry into the causes of that discrepancy should become embedded in organizational memory (the whole of individual and shared maps and images of organizational theory of action) and in organizational routines and procedures.

\section{Learning climate}

The second aspect is learning climate, in which an organization facilitates the learning of its members. Argyris and Schön have inquired into the ways in which the learning climate (or behavioral world) of an organization inhibits or promotes reflection and inquiry. Based on their consulting and seminar experience, Argyris and Schön assert that most organizations are driven by a Model O-I theory of action. This model is characterized by a defensive attitude among individuals and a defensive learning climate in the organization as a whole, making collaborative reflection on and inquiry into the causes of error hard to achieve.

As an alternative to Model O-I, Argyris and Schön advocate a Model O-II theory of action. This model is characterized by an open attitude among individuals and a productive learning climate in the organization as a whole, enabling collaborative reflection and inquiry. Argyris and Schön regard Model O-II as a crucial condition for double-loop

\footnotetext{
1 Argyris and Schön's use of the term deutero-learning is surrounded by terminological ambiguities, making it difficult to distinguish it properly from double-loop learning and to compare it to other forms of higherorder learning. Elsewhere I have discussed these ambiguities and proposed a theoretical reformulation of this term (Visser 2003, 2007).
} 
learning, and double-loop learning in its turn as a crucial condition for organizational survival in the long run. Model O-II organizations, however, are rarely found in practice, and often external interventions are necessary to create a productive learning climate.

Learning at work

The third aspect is learning at work, in which most learning takes place in the workplace and not in formal training courses. Given the difficulties surrounding the transfer of learning and knowledge from the formal training situation to the daily workplace and given the context dependent nature of learning, most learning takes place on-the-job (Holton et al. 2003; Ortenblad 2002, 2004). Argyris and Schön implicitly adopt the same approach, since for them learning is directly tied to error detection and correction in the context of daily work practices.

\section{Learning structure}

The fourth aspect is learning structure, in which an organization has an organic and flexible structure to meet external demands, in three ways. First, such a structure is decentralized, leaving members sufficient discretion to make their own decisions in response to external demands. Second, such a structure is team-based, in which team members are able to replace each other, perform each others' tasks and thus acquire a holistic view of team and organizational functioning. Third, such a structure is flat, although it may be possible that an organic structure is hierarchical (Örtenblad 2002, 2004). Argyris and Schön (1978) implicitly adopt the same approach, when they assert that specialization of work tasks and centralization of power and information in hierarchically structured organizations reinforces Model O-I theories of action and singe-loop learning and thus hinders the doubleloop learning, necessary for long-term survival of the organization.

\section{Case: the Polish campaign and its aftermath}

When the German Army invaded Poland in September 1939, it brought to bear a distinct philosophy of war which acknowledged the existence of environmental uncertainty and turbulence and emphasized the need for a decentralized approach to adapt to it. This philosophy was deeply influenced by the crushing defeat of the Prussian Army at the hands of Napoleon in the Battle of Jena-Auerstedt (1806). In reflecting on the causes of defeat, leading military philosophers and practitioners like Von Clausewitz, Von Scharnhorst, and Von Moltke gradually came to the fundamental insight that friction, uncertainty, and ambiguity are inherent in the "fog of war." These characteristics should be accepted as given, rather than being contained in vain through detailed planning and upper-echelon hierarchical control (Uhle-Wetter 1993; Van Creveld 1983; Widder 2002).

To deal effectively with the "fog of war," German war doctrine increasingly encouraged individual initiative, independent thinking, and responsibility at all levels of command. This doctrinal approach became known as "Auftragstaktik," a command and control system in which commanders were being given missions, rather than orders. In this system "the mission must unmistakably express the will of the commander. The objective, course of action and mission constraints, such as time, must be clear and definite without restricting freedom of action more than necessary in order to make use of the initiative of individuals charged with the tasks to be accomplished. Limits as to the method of 
execution, within the framework of the higher commander's will, are imposed only where essential for coordination with other commands" (Von Lossow 1977, pp. 87-88).

Guided by this doctrine, the German campaign in Poland seemed a devastating success. Within a few weeks, the complete Polish Army (40 divisions, one million men) had been caught in a huge encirclement, with five German armies simultaneously closing in from the German mainland, East Prussia, and from Slovakia (Citino 2004). The Germans prevailed not so much because of "Blitzkrieg," the rapid and bold advance of Panzer and motorized divisions supported by tactical air assaults. They mainly prevailed because of "hardhitting, well-trained infantry, well-supported by artillery, and tactical air assets" (Newland 2004, p. 87). Of the 54 divisions committed in that campaign, only seven were Panzer, four were motorized, and four mechanized light divisions; the rest was infantry, largely horsedrawn, and not motorized. Further, the Germans made optimal use of radio in "holding together... air assets, mechanized spearheads, follow-on infantry and the huge supply chain" (Citino 2004, p. 339). For example, when a Polish counterattack east of Warsaw threatened two German infantry divisions, within a week the motorized units of the 8th Army shifted their course $180^{\circ}$ to divert the Polish counterattack and, after accomplishing this mission, shifted again $180^{\circ}$ to hurry back on their original course to Warsaw. The Polish forces suffered from poor communications, forcing their units to attack in isolation and without support (Peszke 1979).

In spite of its smooth appearance and although most political, strategic, and operational factors were favorable to the German side, the Polish campaign was not the flawless success Nazi propaganda quickly made of it. After only 18 days of fighting, the German Army had almost completely run out of petrol, weapons, and ammunition (Frieser 2005; Peszke 1979). Furthermore, it had suffered huge equipment losses. Due to poor roads and rough terrain tanks, armored vehicles and trucks broke down in large numbers (by the end of September the whole XIX Panzer Corps was temporarily immobilized for this reason). In the whole Polish campaign the Germans lost no less than 217 tanks, making it anything but an "exercise with live ammunition" (Peszke 1979, p. 23).

Not surprisingly, the German Army high command ("Oberkommando des Heeres," hereafter $\mathrm{OKH}$ ) was not satisfied with many aspects of the Polish campaign. Directly after the end of the campaign in October 1939, the Army commander-in-chief, Colonel-General Von Brauchitsch, ordered his corps and division commanders to come up with as critical, honest and realistic after action reports ("Erfahrungsberichte") as possible. In the same spirit, these senior commanders in their turn should collect after action reports from their subordinate commanders down to regimental level. Within 1 month these reports were written, collected, and passed on to OKH (Hart 2001; Murray 1981, 1992). In general lower commanders were not afraid to give critical and accurate accounts of their units' performance, indicating a high level of trust and honesty between echelons that seemed characteristic of the German Army throughout World War II (Van Creveld 1983; Uhle-Wetter 1993).

On the basis of the assembled "Erfahrungsberichte," OKH concluded that the Polish campaign had confirmed basic doctrine and principles of German operational warfare, but also had revealed important deficiencies in the functioning of light mechanized divisions, in reconnaissance, coordination, camouflage skills, and in night fighting. Infantry was generally lacking aggressiveness and depended too much on artillery to crush enemy positions. Armor had been too much dispersed, poorly coordinated, and lacking in march discipline (Hart 2001). Further, OKH concluded that several of these basic principles needed reemphasis and retraining, in particular effective combat leadership and initiative at all levels of command, cooperation between weapons and branches, and elastic defense in depth (Murray 1981). 
However, when in November 1939 Von Brauchitsch confronted Hitler with these deficiencies and the retraining challenges they posed, Hitler went into a rage and threatened to dismiss him on the spot. Underrating Allied strength and believing that time was on his side, Hitler wanted an attack on Western Europe as quickly as possible, from which plan his military advisors could only dissuade him on the grounds of unfavorable weather conditions (Frieser 2005).

Under this political pressure, $\mathrm{OKH}$ frantically set out to convert the lessons of the Polish campaign into a vast, 6-months (re)training program, not only for the units that had been involved in that campaign, but also, and even more importantly, for the numerous new units and existing reserve units that Hitler intended to commit against the West in the Spring of 1940. In that program, OKH directly tied the lessons of Poland to the training of existing and new troops, emphasizing the importance of combat leadership of officers and non-commissioned officers (NCOs) and the importance of discipline and order as a basis for victory. The General Staff's training section developed a detailed set of objectives and standards for training in the various schools of the German Army, where officers and NCOs with recent combat experience were brought in as instructors (Hart 2001; Murray 1981; Van Creveld 1983).

The training program worked from the bottom up, first developing the capabilities of individual soldiers, then working on performance improvement at platoon and company levels, and finally ending with large scale exercises at battalion and regimental levels. For commanding officers a special training division was set up, organizing 3- to 4-week courses through which 300 officers passed each time (Frieser 2005). Officers (and NCOs) at all levels of command were inculcated with the need to lead from up front, take initiative, and employ decisive action, in line with the doctrine of "Auftragstaktik." Throughout the 6 months, training was methodical, detailed, and rigorous, approaching real combat conditions as close as possible. Often men and officers were exerted to their mental and physical limits to foster unit cohesion and to determine who could endure real battle and who could not (Hart 2001; Murray 1981).

The important role of doctrine and training became visible in the campaign in the West in May 1940. Within 6 weeks, the German Army defeated the French, Belgian, and Dutch armies and the British Expeditionary Forces. The Germans prevailed because of the boldness, speed, and unpredictability of their spearhead Panzer and motorized divisions, which continuously threw the methodical, defensive, and cautiously reacting French Army high command off balance (Alexander 2007; Frieser 2005). Since, however, only 16 out of 157 committed divisions were fully motorized, a considerable role in the campaign was also played by conventional infantry, displaying a large amount of "battlefield improvisation made possible by the superior leadership and training of the German soldier" (Kiesling 2007, p. 883). All this happened although the German Army still was inferior to the Allied forces in number of soldiers, divisions, artillery pieces, aircraft, and in terms of quality and quantity of tanks, still had a shortage of sufficiently trained officers (in spite of the training efforts), and still showed deficiencies in motorization, logistics, and artillery capabilities (Frieser 2005; Hart 2001).

\section{Case analysis}

Applying the model of Örtenblad and the framework of Argyris and Schön to German Army operations between 1939 and 1940 reveals that all four aspects clearly or to some 
extent play a role, supporting the assertion that this army was organized in accordance with many aspects currently associated with the learning organization.

The aspect of organizational learning is clearly present in the case. The German Army did learn in Argyris and Schön's sense in that a number of actually occurring consequences in the Polish campaign did not conform to the consequences the Germans expected on the basis of their doctrine and principles. This discrepancy gave rise to a process of reflection and inquiry, in which the after action reports of various units played a central role, to detection, and ultimately to correction of the perceived errors. Furthermore, this learning by the German Army was organizational to the extent that the lessons learned from the "Erfahrungsberichte" were as quickly and thoroughly as possible converted by OKH and the General Staff into guidelines for a vast (re)training program for existing and new units. Through a methodical and rigorous implementation of the program the experiences of the Polish campaign were within 6 months incorporated in the combat routines and procedures of the German Army as a whole. The dominant type of learning in the German Army seemed to have been single loop, since the norms and values underlying existing doctrine and principles were not seriously questioned. Instead, $\mathrm{OKH}$ emphasized that various combat practices needed to be upgraded in line with prevalent norms and standards.

The aspect of learning climate is also clearly present in the case. In the German Army learning seemed to have been possible, due to a relatively open and productive learning climate, even in spite of political pressure. Senior Army commanders, most notably the commander-in-chief himself, insisted on critical and accurate after action reports from lower commanders, who in their turn were not afraid to issue such reports. Relatively high levels of mutual trust and honesty were characteristic of communication between different echelons, facilitating the exchange of accurate information up and well-informed mission orders down the German chain of command. All these aspects point in the direction of a Model O-II theory of action and a productive learning climate, which Argyris and Schön advocate for double loop learning, but which they rarely found in practice.

The aspect of learning at work is to some extent present in the case. In the German Army learning seemed to have been occurring mostly in formal training programs. However, these programs were closely tied to the lessons learned in the Polish campaign and to existing doctrine, while the actual training, carried out under the guidance of combat veterans, approached real battle conditions as close as possible. Under these conditions the transfer of learning from the training situation to the workplace may have been less difficult than in other organizations under different conditions.

The aspect of learning structure is also to some extent present in the case. In the German Army decision-making was decentralized and the need for decisive action at all levels of command was emphasized, in accordance with the doctrine of "Auftragstaktik." Further, much emphasis was laid on the development of unit cohesion, in which officers, NCO's, and men came to know each other intimately and were able to replace each other in case of war attrition. Finally, like all armies, the German Army was characterized by a hierarchical structure, but this was compensated by decentralized decision-making and high levels of trust between echelons.

\section{Conclusions and discussion}

The past example of the German case suggests that it is possible to combine aspects associated with the learning organization with conditions of hierarchy and discipline. Under such conditions, empowerment, trust, and leadership become crucial elements in 
sustaining learning (cf. Jamali et al. 2006; Popper and Lipshitz 2000). From the lowest echelons upward, organization members and junior leaders must be accorded considerable leeway in performing their tasks, as long as they remain within the organization's specific mission and goals. They must be thoroughly educated and trained to assume responsibility, take initiative, and decisive action whenever possible and necessary to accomplish that mission. With lower echelon initiative and action the possibilities of errors increase, and with these the opportunities for learning. As much as the higher echelons should trust their members and junior leaders to undertake responsible action, the latter should trust their superiors to maintain an open learning climate and to treat errors as learning opportunities, not as occasions for punishment. The attitude of senior leaders is crucial in this respect, especially in hierarchical organizations.

The German example from the past has implications for present organizations. In the first place, they are pertinent for army organizations. After World War II many armies have formally embraced German doctrine and principles of warfare, especially the doctrine of mission command ("Auftragstaktik"). In particular the US Army, at present the world's most powerful army, champions these tactics. It explicitly strives to become an army that intends to learn from past mistakes through the establishment of a Center for Army Lessons Learned (e.g., Baird et al. 1997; Chua et al. 2006; Wheatley 1994), and through a more systematic use of after action reviews (e.g., Baird et al. 1999; Darling et al. 2005). However, the existence of this separate Center also suggests that learning is not normally or sufficiently practiced in the US Army's line organization, whereas in the German Army this was part of daily routine, actively encouraged by senior commanders and crucially important for the improvement of training and doctrine. More in general, many observers note that mission command and learning seem to be more theory than practice in the US Army, which is still characterized by detailed planning, command, and control from the top down (e.g., Boothe 2005; Clemons and Santamaria 2002; Dunivan 2003; Leonhard 1993).

In the second place, the implications of the German case are pertinent for civilian organizations that share one or more army features, like prisons, correctional facilities, police forces, hospitals, mental institutions, and fire departments. Like armies, such organizations more or less regularly deal with emotionally intense life-death emergency situations, they acknowledge the necessity of strong unit cohesion and clear leadership in such emergencies, and they are all more or less characterized by an inclusive atmosphere. Furthermore, they all must to some extent balance conditions of hierarchy and discipline with the need for flexibility and rapid adaptation to emergencies (e.g., Amitay et al. 2005; Visser 2007). In a wider sense, the implications of this case also are pertinent for other bureaucratic organizations that strive to become learning organizations (Jamali et al. 2006; Wilson 1989).

Armies, more or less "army-like" civilian organizations, and bureaucratic organizations striving to be learning organizations must think systematically and holistically about combining conditions of hierarchy and discipline with the need for empowerment, trust, and leadership, in order to remain flexible and adaptive. It will not be sufficient to single out one aspect, like learning from after action reports, if this is not further embedded in other aspects of the organization. The results of such learning, for example, must be embedded in organizational memory, systems, routines, and training practices in order to reach all corners of the organization. Such learning must be conducted in a productive learning climate to be really effective. Such learning must have direct implications for daily work practices. Such learning must be actively propagated from the top down and be carried out with the same discipline as the regular tasks of the organization. Most importantly, hierarchical organizations must resist the ever-present temptation toward centralization and more detailed command and control from the top down, so that the lower 
echelons may have meaningful decision-making discretion and with it the opportunity lo learn from the consequences of good and bad decisions.

Finally, two cautionary notes on the German case are in order. In the first place, the operations of the German Army must be placed in a larger (geo)political picture. The specific culture and operations of the Army in this period were sharply circumscribed by the context of Hitler's national-socialist policies and institutions. Matters of strategy, politics, and economics largely were beyond the Army's sphere of influence and competence. In the course of World War II, German Army operations could not overcome political and strategic blundering. By being effectively and efficiently instrumental in the implementation of poor political and strategic decisions, the Army partially masked this poor quality and unnecessarily prolonged an already lost war. The worst political and strategic mistake, most military historians agree, was waging a two-front war against the combined Allied forces, given the uneven balance of industrial, logistical, and human resources between German and Allied forces (e.g., Beaumont 1986; Frieser 2005; Murray 1992; Van Creveld 1988).

In the second place, with this paper I do not intend to diminish the responsibility of the German Army for World War II war crimes and genocide, which by many accounts was considerable (e.g., Bartov 1991; Beaumont 1986; Hart 2001), nor do I wish to engage in revisionist history (re)writing. Yet, six decades after the end of the war an attempt may be made to extract some positive lessons from this tragedy. The German Army was a very effectively learning fighting machine, whose principles of organization and operation found their way and contributed to the rapid postwar economic recovery of Germany (Glunk et al. 1996). However, with the Allied victory these principles quickly were replaced by the management concepts of the victors, in particular those of American stock (Hofstede 1993). This paper represents an attempt to recover these older German principles and to place them in the service of more peaceful and socially useful purposes.

Acknowledgments I thank Anders Örtenblad, Mike Geppert, Jaap Jan Brouwer and the two anonymous reviewers for their stimulating and critical comments on earlier versions of this paper.

Open Access This article is distributed under the terms of the Creative Commons Attribution Noncommercial License which permits any noncommercial use, distribution, and reproduction in any medium, provided the original author(s) and source are credited.

\section{References}

Alexander, M. S. (2007). After Dunkirk: The French Army's performance against "Case Red", 25 May to 25 June 1940. War in History, 14, 219-264. doi:10.1177/0968344507075873.

Amitay, M., Popper, M., \& Lipshitz, R. (2005). Leadership styles and organizational learning in community clinics. The Learning Organization, 12, 57-70. doi:10.1108/09696470510574269.

Argyris, C., \& Schön, D. A. (1974). Theory in practice: Increasing professional effectiveness. San Francisco: Jossey-Bass.

Argyris, C., \& Schön, D. A. (1978). Organizational learning: A theory of action perspective. Reading, MA: Addison-Wesley.

Argyris, C., \& Schön, D. A. (1996). Organizational learning II: Theory, method and practice. Reading, MA: Addison-Wesley.

Baird, L., Henderson, J. C., \& Watts, S. (1997). Learning from action: An analysis of the Center for Army Lessons Learned (CALL). Human Resource Management, 36, 385-395. doi:10.1002/(SICI)1099050X(199724)36:4 $\leq 385:: A I D-H R M 3 \geq 3.0 . C O ; 2-R$.

Baird, L., Holland, P., \& Deacon, S. (1999). Learning from action: Imbedding more learning into the performance fast enough to make a difference. Organizational Dynamics, 27(4), 19-32. doi:10.1016/ S0090-2616(99)90027-X. 
Bartov, O. (1991). Soldiers, Nazis and war in the Third Reich. The Journal of Modern History, 63, 44-60. doi: $10.1086 / 244258$.

Beaumont, R. A. (1986). On the Wehrmacht mystique. Military Review, 66(7), 44-56.

Boothe, L. L. (2005). OPORDs and leadership: Complicating simplicity. Military Review, 85(5), 75-79.

Chua, A. Y. K., Lam, W., \& Majid, S. (2006). Knowledge reuse in action: The case of CALL. Journal of Information Science, 32, 251-260. doi:10.1177/0165551506064384.

Citino, R. M. (2004). Beyond fire and movement: Command, control and information in the German "Blitzkrieg". The Journal of Strategic Studies, 27, 324-344. doi:10.1080/0140239042000255940.

Clemons, E. K., \& Santamaria, J. A. (2002). Maneuver warfare: Can modern military strategy lead you to victory? Harvard Business Review, 80(4), 56-65.

Darling, M., Parry, C., \& Moore, J. (2005). Learning in the thick of it. Harvard Business Review, 83(7), 84-93.

Dunivan, J. (2003). C2 on the digitized battlefield: Surrendering the initiative? Military Review, 83(5), 2-10.

Dupuy, T. N. (1984). A genius for war: The German Army and General Staff, 1807-1945. Fairfax, VA: Hero.

Easterby-Smith, M., \& Lyles, M. A. (2003). Re-reading organizational learning: Selective memory, forgetting and adaptation. Academy of Management Executive, 17(2), 51-55.

Easterby-Smith, M., Antonacopolou, E., Simm, D., \& Lyles, M. A. (2004). Constructing contributions to organizational learning: Argyris and the next generation. Management Learning, 35, 371-380. doi: $10.1177 / 1350507604048268$.

Frieser, K.-H. (2005). The "Blitzkrieg" legend: The 1940 campaign in the West. Annapolis, MD: Naval Institute Press.

Glunk, U., Wilderom, C., \& Ogilvie, R. (1996). Finding the key to German-style management. International Studies of Management and Organization, 26(3), 93-108.

Hart, R. A. (2001). Clash of arms: How the Allies won in Normandy. Boulder, CO: Lynne Rieger.

Hofstede, G. (1993). Cultural constraints in management theories. Academy of Management Executive, 7(1), 81-94.

Holton, E. F., Chen, H.-C., \& Naquin, S. S. (2003). An examination of learning transfer system characteristics across organizational settings. Human Resource Development Quarterly, 14, 459-482. doi: 10.1002/hrdq.1079.

Jamali, D., Khoury, G., \& Sahyoun, H. (2006). From bureaucratic organizations to learning organizations: An evolutionary roadmap. The Learning Organization, 13, 337-352. doi:10.1108/09696470610667724.

Kiesling, E. C. (2007). Illuminating "Strange Defeat" and "Pyrrhic Victory": The historian Robert A. Doughty. The Journal of Military History, 71, 875-888. doi:10.1353/jmh.2007.0212.

Leonhard, R. R. (1993). Maneuver warfare and the United States Army. In R. D. Hooker (Ed.), Maneuver warfare: An anthology (pp. 42-56). Novato, CA: Presidio.

March, J. G., \& Weissinger-Baylon, R. (1986). Introduction. In J. G. March \& R. Weissinger-Baylon (Eds.), Ambiguity and command: Organizational perspectives on military decision-making (pp. 1-7). Marshfield, MA: Pitman.

Morgan, G. (1997). Images of organization (2nd ed.). Thousand Oaks, CA: Sage.

Moskos, C. C. (1984). The sociology of combat. Contemporary Sociology, 13, 420-422. doi:10.2307/ 2069041.

Murray, W. (1981). The German response to victory in Poland: A case study in professionalism. Armed Forces and Society, 7, 285-298. doi:10.1177/0095327X8100700209.

Murray, W. (1992). German military effectiveness. Baltimore, MD: Nautical and Aviation Publishing.

Mutch, A. (2006). Organization theory and military metaphor: Time for a reappraisal? Organization, 13, 751-769. doi:10.1177/1350508406068503.

Newland, S. J. (2004). “Blitzkrieg” in retrospect. Military Review, 84(4), 86-89.

Örtenblad, A. (2002). A typology of the idea of learning organization. Management Learning, 33, $213-230$. doi: $10.1177 / 1350507602332004$.

Örtenblad, A. (2004). The learning organization: Towards an integrated model. The Learning Organization, 11, 129-144. doi:10.1108/09696470410521592.

Örtenblad, A. (2007). Senge's many faces: Problem or opportunity. The Learning Organization, 14, 108122. doi:10.1108/09696470710726989.

Peszke, M. A. (1979). Poland's preparation for World War Two. Military Affairs, 43, 18-25. doi:10.2307/ 1987383.

Popper, M., \& Lipshitz, R. (2000). Installing mechanisms and instilling values: The role of leaders in organizational learning. The Learning Organization, 7, 135-144. doi:10.1108/09696470010335854.

Senge, P. M. (1990). The fifth discipline: The art and practice of the learning organization. New York: Doubleday Currency. 
Talbot, P. A. (2003). Management organizational history-a military lesson? Journal of European Industrial Training, 27, 330-340. doi:10.1108/03090590310490007.

Tsang, E. W. K. (1997). Organizational learning and the learning organization: A dichotomy between descriptive and prescriptive research. Human Relations, 50, 73-89.

Uhle-Wetter, F. (1993). Auftragstaktik: Mission orders and the German experience. In R. D. Hooker (Ed.), Maneuver warfare: An anthology (pp. 236-247). Novato, CA: Presidio.

Van Creveld, M. (1983). Fighting power: German and US Army performance, 1939-1945. London: Arms and Armor.

Van Creveld, M. (1988). On learning from the Wehrmacht and other things. Military Review, 68(1), 62-71.

Visser, M. (2003). Gregory Bateson on deutero-learning and double bind: A brief conceptual history. Journal of the History of the Behavioral Sciences, 39, 269-278. doi:10.1002/jhbs.10112.

Visser, M. (2007). Deutero-learning in organizations: A review and a reformulation. Academy of Management Review, 32, 659-667.

Von Lossow, W. (1977). Mission-type tactics versus order-type tactics. Military Review, 57(6), 87-91.

Wheatley, M. J. (1994). Can the US Army become a learning organization? Journal for Quality and Participation, 17(2), 50-55.

Widder, W. (2002). “Auftragstaktik" and "Innere Führung”: Trademarks of German leadership. Military Review, 82(5), 3-9.

Wilson, J. Q. (1989). Bureaucracy: What government agencies do and why they do it. New York: Basic Books. 